\title{
Perbedaan Hasil Belajar IPS Antara Model Pembelajaran Konvensional Berbantuan Media Gambar dengan Model Pembelajaran Talking Stick Berbantuan Media Power Point di Kelas III SDN Turirejo 02 Lawang Malang Tahun Ajaran 2015/2016
}

\author{
Linda Yulianti ${ }^{1}$, Dyah Tri Wahyuningtyas ${ }^{2}$ \\ ${ }^{1,2}$ Universitas Kanjuruhan Malang \\ dyahtriwahyu@unikama.ac.id
}

\begin{abstract}
Abstrak
Penelitian ini bertujuan untuk mengetahui perbedaan hasil belajar ips antara model pembelajaran konvensional berbantuan media gambar dengan model pembelajaran talking stick berbantuan media power point di Kelas III SDN Turirejo 02 Lawang Malang Tahun Ajaran 2015/2016. Jenis penelitian menggunakan pendekatan kuantitatif dengan metode comparasi eksperimen. Sampel dalam penelitian ini adalah siswa Kelas III SDN Turirejo 02 Lawang Malang Tahun Ajaran 2015/2016 sebanyak 62 siswa dengan rincian kelas IIIA sebanyak 31 siswa sebagai kelas eksperimen dan kelas IIIB sebanyak 31 siswa sebagai kelas kontrol. Teknik pengambilan data melalui dokumentasi berupa nilai pretest dan posttest. Hasil penelitian menunjukkan bahwa nilai $\mathrm{t}$ sebesar -5.509 untuk kelompok kontrol dan kelompok eksperimen memiliki signifikan sebesari 0.000 yang berarti lebih kecil dari signifikan 0,05 . Berdasarkan hasil penelitian di atas dapat disimpulkan bahwa terdapat perbedaan antara model pembelajaran konvensional berbantuan media gambar dengan model pembelajaran talking stick berbantuan media power point terhadap hasil belajar.
\end{abstract}

Kata Kunci: hasil belajar, IPS, konvensional, media gambar, media power point, talking stick

\begin{abstract}
This study aims to determine differences in learning outcomes of ips between conventional learning model assisted media images with the learning model of talking stick assisted media power point in Class III SDN Turirejo 02 Lawang Malang School Year 2015/2016. This research uses quantitative approach with experimental comparation method. The sample in this study is the students of Class III SDN Turirejo 02 Lawang Malang School Year 2015/2016 as many as 62 students with class IIIA details as many as 31 students as experimental class and class IIIB as many 31 students as control class. Technique of taking data through documentation in the form of pretest and posttest value. The results showed that the $t$ value of -5.509 for the control group and the experimental group had significant sebesari 0.000 which means smaller than significant 0.05. Based on the results of the above research can be concluded that there is a difference between conventional learning model assisted image media with the learning model of talk stick powered media point aid to learning outcomes.
\end{abstract}

Keywords: learning result, IPS, conventional, image media, power point media, talking stick 


\section{PENDAHULUAN}

Pendidikan IPS disekolah Dasar merupakan bidang studi yang mempelajari manusia dalam semua aspek kehidupan dan interaksinya dalam masyarakat. Peranan IPS penting untuk mendidik siswa mengembangkan pengetahuan, sikap, dan keterampilan agar dapat mengambil bagian secara aktif dalam kehidupannya kelak sebagai anggota masyarakat dan warga negara yang baik. Tujuan pendidikan Ilmu Pengetahuan Sosial adalah mendidik dan memberi bekal kepada siswa untuk mengembangkan diri sesuai bakat, minat, kemampuan, lingkungan. Bekal tersebut akan digunakan siswa untuk melanjutkan kejenjang yang lebih tinggi (Solihatin dan Raharjo, 2008:15).

Berdasarkan hasil observasi yang dilakukan oleh peneliti di SDN Turirejo 02 Lawang saat pembelajaran IPS berlangsung, guru sudah berusaha menyajikan materi dengan baik, diantaranya guru menggunakan metode ceramah, tanya jawab, dan penugasan. Tetapi siswa masih saja kurang perhatian dalam mengikuti proses pembelajaran di kelas. Ada siswa yang berbicara dengan temannya sehingga membuat suasana kelas menjadi gaduh, ada juga yang menggangu temannya, ada yang terlihat serius tetapi ternyata sedang melamun, serta aktifitas siswa dalam pembelajaran masih kurang yaitu diantaranya aktifitas bertanya, sehingga pencapaian hasil belajar siswa setelah dilakukan evaluasi kurang maksimal.

Berdasarkan hasil observasi, Guru perlu memilih model yang tepat untuk mengajarkan IPS kepada siswa, sehingga membuat siswa lebih aktif, antusias, senang mengikuti pembelajaran serta lebih mudah memahami materi yang diberikan sehingga hasil belajar yang diperoleh menjadi lebih bagus. Penggunaan model pembelajaran yang tepat, diharapkan dapat mewujudkan tujuan pembelajaran yang diharapkan. Dengan penggunaan model pembelajaran yang tepat, maka materi yang disampaikan akan mudah diterima dan mudah diingat, dapat memotivasi siswa terhadap materi yang dipelajari. Untuk itu maka dalam melaksanakan pembelajaran guru hendaknya menggunakan model pembelajaran yang sesuai dengan materi dan tujuan pembelajaran. Dalam pembelajaran Ilmu Pengetahuan Sosial (IPS), guru harus betul-betul menetapkan tujuan yang ingin dicapai, bahan pembelajaran yang akan disampaikan serta memilih model dan 
media yang relevan. Karena dengan menggunakan model yang tepat dan media yang menarik siswa akan tertarik dan lebih memusatkan perhatian serta merangsang kreativitasnya, sehingga siswa akan lebih mudah memahami materi yang diberikan sehingga hasil belajar siswa pun akan lebih bagus.

Berdasarkan uraian tersebut, maka peneliti berinisiatif untuk menerapkan model pembelajaran talking stick. Model pembelajaran talking stick merupakan salah satu model pembelajaran kooperatif. Menurut Suprijono (2010:109) pembelajaran dengan strategi talking stick mendorong peserta didik untuk berani mengemukakan pendapat. Strategi ini diawali dengan penjelasan guru mengenai materi pokok yang akan dipelajarai.

Pembelajaran IPS dengan menggunakan model pembelajaran talking stick ini dapat menciptakan suasana belajar yang menyenangkan. Dalam pembelajaran siswa akan terdorong untuk memperhatikan guru karena siswa harus siap memberikan jawaban apabila mendapat pertanyaan dari guru tentang materi yang sedang diajarkan. Pembelajaran IPS dengan menggunakan model pembelajaran talking stick akan lebih optimal bila dibantu dengan penggunaan media penggunaan media pembelajaran. Pada penelitian ini, peneliti akan menggunakan media berbasis multimedia yaitu media power point yang akan membantu proses penggunaan model pembelajaran talking stick.

Media ini akan menampilkan materi yang akan disampaikan guru yang salah satunya gambar yaitu tentang gambar jenis-jenis pekerjaan yang akan disajikan dengan semenarik mungkin agar siswa tertarik untuk mengikuti pembelajaran, selain itu juga akan memudahkan siswa untuk mengingat materi yang telah disampaikan oleh guru. Sehingga tujuan pembelajaran IPS akan tercapai. Hal ini dibuktikan dari hasil penelitian yang dilakukan oleh Muhammad Zam Zam Rizka Susila Ardi (2012) yang hasil penelitian menunjukkan bahwa model pembelajaran talking stick mempunyai pengaruh yang lebih baik terhadap hasil belajar siswa dibanding dengan pembelajaran konvensional.

Tujuan penelitian ini adalah mengetahui apakah ada perbedaan hasil belajar IPS antara model pembelajaran konvensional berbantuan media gambar dengan model pembelajaran talking stick berbantuan media power point di Kelas III SDN Turirejo 02 Lawang Malang Tahun Ajaran 2015/2016. 


\section{METODE PENELITIAN}

Pendekatan yang digunakan dalam penelitian ini adalah pendekatan kuantitatif. Alasan peneliti menggunakan pendekatan kuantitatif karena peneliti bermaksud untuk menghilangkan subjektifitas dalam penelitian serta mendapatkan data yang valid Arifin (2012:29). Penelitian ini terdapat dua variabel yaitu variabel bebas (model pembelajaran konvensional berbantuan media gambar dengan model pembelajaran talking stick berbantuan media power point) dengan variabel terikat (hasil belajar). Jenis penelitian yang digunakan dalam penelitian ini adalah Komparasi eksperimen. Desain yang digunakan adalah desain kelompok kontrol non-ekuivalen (nonequivalent control group design). Dalam penelitian ini terdapat dua kelompok yakni kelompok eksperimen dan kelompok kontrol yang tidak diambil secara acak (Sugiyono, 2011:116).

Kelompok eksperimen akan diberikan suatu tindakan yang disebut treantment yang artinya pemberian kondisi yang akan dinilai pengaruhnya. Kelompok eksperimen adalah kelompok yang diberikan treatment atau perlakuan tertentu. Kelompok kontrol adalah kelompok dengan pembelajaran seperti biasa, sedangkan kelompok eksperimen diberikan treatment dengan menggunakan model pembelajaran talking stick berbantuan media power point. Setelah itu kedua kelas tersebut akan diberikan pretest yang bertujuan untuk mengetahui kemampuan awal siswa da untuk mengetahui bahwa kelompok eksperimen dan kelompok kontrol dalamkeadaan yang sama. Selanjutnya pemberian posttest akan diberikan diakhir penelitian untuk mengukur pemahaman dan penguasaan materi selama proses pembelajaran. Kedua kelas tersebut yaitu kelas IIIA dan IIIB samasama diberikan soal yang mempunyai bobot yang sama. Desain eksperimen yang dilakukan dalam penelitan ini adalah desain kelompok kontrol non-ekuivalen seperti yang digambarkan berikut ini :

\begin{tabular}{|lll|}
\hline Kelompok eksperimen & $:$ & $O_{1} \times O_{2}$ \\
Kelompok kontrol & $:$ & $O_{3}-O_{4}$ \\
\hline
\end{tabular}

Keterangan :

$O_{1}$ : pengukuran kemampuan awal kelompok eksperimen $\mathrm{O}_{2}$ : Pengukuran kemampuan akhir kelompok eksperimen $\mathrm{X}$ : Pemberian perlakuaan atau treatment 
$\mathrm{O}_{3}$ : Pengukuran kemampuan awal kelompok kontrol

$\mathrm{O}_{4}$ : Pengukuran kemampuan akhir kelompok kontrol

Populasi dalam penelitian ini adalah sebesar 62 siswa yang terdiri dari kelas 3B sebanyak 31 siswa dan kelas 3A sebanyak 31 siswa. Teknik pengambilan sampling yang digunakan dalam penelitian ini adalah teknik sampling non probability sampling.

\section{HASIL DAN PEMBAHASAN}

Berdasarkan hasil penelitian di Kelas III SDN Turirejo 02 Lawang diperoleh hasil penelitian yakni Hasil uji T menunjukkan nilai t sebesar -5.509 untuk kelompok kontrol dan kelompok eksperimen memiliki signifikan sebesar 0.000 yang berarti lebih kecil dari signifikan 0,05 . Hal ini membuktikan bahwa ada perbedaan hasil belajar ips antara model pembelajaran konvensional berbantuan media gambar dengan model pembelajaran talking stick berbantuan media power point di Kelas III SDN Turirejo 02 Lawang Malang Tahun Ajaran 2015/2016.

Pembelajaran IPS dengan menggunakan model pembelajaran talking stick ini dapat menciptakan suasana belajar yang menyenangkan. Dalam pembelajaran siswa akan terdorong untuk memperhatikan guru karena siswa harus siap memberikan jawaban apabila mendapat pertanyaan dari guru tentang materi yang sedang diajarkan. Pembelajaran IPS dengan menggunakan model pembelajaran talking stick akan lebih optimal apabila dibantu dengan penggunaan media pembelajaran. Pada penelitian ini, peneliti akan menggunakan media berbasis multimedia yaitu media power point yang akan membantu proses penggunaan model pembelajaran talking stick.

Media ini akan menampilkan materi yang akan disampaikan guru yang salah satunya gambar yaitu tentang gambar jenis-jenis pekerjaan yang akan disajikan dengan semenarik mungkin agar siswa tertarik untuk mengikuti pembelajaran, selain itu juga akan memudahkan siswa untuk mengingat materi yang telah disampaikan oleh guru. Sehingga tujuan pembelajaran IPS akan tercapai. Hal ini dibuktikan hasil penelitian Penelitian yang dilakukan oleh 
Muhammad Zam Zam Rizka Susila Ardi (2012) dengan judul "Peningkatan Kualitas Pembelajaran IPS melalui Model Talking stick dengan media CD pada siswa kelas IV SDN Tawang Mas 01". Hasil penelitian menunjukkan peningkatan pencapaian ketuntasan belajar siklus I (61\%), siklus II (72\%), dan pada siklus III (89\%). Penelitian ini didukung oleh penelitian Winarsih dengan judul "Penerapan Model Talking stick untuk meningkatkan Hasil Belajar IPS kelas IV di SDN Blabak Kota Kediri”. Hasil penelitian menunjukkan peningkatan kualitas pembelajaran pada siklus kedua sebesar 83\%. Hasil penelitian menunjukkan bahwa model pembelajaran talking stick mempunyai pengaruh yang lebih baik terhadap hasil belajar siswa dibanding dengan pembelajaran konvensional.

Pada uji hipotesis telah diketahui bahwa ada perbedaan hasil belajar ips antara model pembelajaran konvensional berbantuan media gambar dengan model pembelajaran talking stick berbantuan media power point di Kelas III SDN Turirejo 02 Lawang Malang Tahun Ajaran 2015/2016. Pada kelas eksperimen diberi treatment dengan menggunakan model pembelajaran talking stick berbantuan media power point sedangkan pada kelas kontrol menggunakan model pembelajaran konvensional berbantuan media gambar. Jika dilihat dari paparan sebelumnya diketahui bahwa pada kelas eksperimen terjadi peningkatan kemampuan siswa setelah perlakuan sebesar 5,8 atau 19\% sedangkan pada kelas kontrol peningkatan terjadi sebesar 1,6 atau 5\% itu berarti jelas terdapat perbedaan hasil belajar siswa.

Jika dilihat dari nilai posttest siswa, diketahui pada perbedaan ini terjadi secara positif, artinya kelas yang diberikan perlakuan khusus meningkat lebih tinggi jika dibandingkan dengan kelas yang tidak diberikan perlakuan khusus berupa model pembelajaran talking stick berbantuan media power point. Dalam proses pembelajaran juga terdapat perbedaan, yaitu pada kelas eksperimen siswa lebih aktif dalam pembelajaran, sedangkan pada kelas kontrol siswa cenderung pasif.

\section{KESIMPULAN DAN SARAN}

Berdasarkan hasil analisis yang telah dikemukakan pada bab IV, maka dapat ditarik beberapa kesimpulkan bahwa: nilai t sebesar -5.509 untuk kelompok 
kontrol dan kelompok eksperimen memiliki signifikan sebesari 0.000 yang berarti lebih kecil dari signifikan 0,05. Hal ini membuktikan bahwa ada perbedaan hasil belajar ips antara model pembelajaran konvensional berbantuan media gambar dengan model pembelajaran talking stick berbantuan media power point di Kelas III SDN Turirejo 02 Lawang Malang Tahun Ajaran 2015/2016. Berdasarkan hasil penelitian ini, maka saran yang diajukan adalah penggunaan model pembelajaran talking stick berbantuan media power point dapat berpengaruh terhadap hasil belajar siswa. Serta penelitian ini dapat dijadikan acuan guru untuk memilih model pembelajaran yang sesuai untuk materi dan pembelajaran yang akan diajarkan kepada siswa. Untuk memberikan semangat belajar disekolah khususnya mata pelajaran IPS materi Jenis-jenis pekerjaan dan memberikan kemudahan siswa untuk menerima pelajaran yang disampaikan oleh guru. Sebagai masukan dan bahan referensi bagi Kepala sekolah untuk memberikan pengarahan kepada guru dalam kegiatan belajar mengajar untuk meningkatkan hasil belajar siswa. Menjadi bahan referensi bagi para peneliti yang mampu melaksanakan pembelajaran dengan efektif dan efisien.

\section{DAFTAR PUSTAKA}

Anitah, Sri. 2010. Media Pembelajaran. Surakarta: Yama Pustaka.

Arikunto, Suharsimi.2010.Prosedur Penelitian Suatu Pendekatan Praktik. Jakarta:Rineka Cipta.

Arifin, Zainal. 2012. Penelitian Pendidikan Metode dan Paradigma Baru. Bandung: PT. Remaja Rosdakrya.

Arifin, Zainal. 2013. Evaluasi pembeljaran (cetakan ke-5). Bandung: PT. Remaja Rosdakarya.

Daryanto. 2012. Media Pembelajaran. Bandung: PT Sarana Tutorial Nurani Sejahtera.

Gunawan, Imam. 2013. Metode penelitan Kuantitatif: Teori dan Praktek. Jakarta: Bumi Aksara

Hadi, Susilo dkk. 2008. Kajian Ilmu Pengetahuan Sosial. Salatiga: Widya Sari Press. 